\title{
Non-Verbal Communication and Management of Interactive Conflict in School-based Violence: A Sociological Perspective
}

\author{
Alexander O. Iyekolo
}

\begin{abstract}
A school environment, like any other open society, is an avenue where a series of conflicts are often manifested as school-staff and students relate on a daily basis to discharge their social and academic business. When these conflicts are not adequately managed, they can result in serious school-based violence. Thus, this paper presents a systematic analysis of how elements of non-verbal communication among school-staff and students can be managed to prevent occurrences of academic and administrative conflicts that can hamper achieving the goals of the school system.
\end{abstract}

Keywords: non-verbal communication, management of interactive conflicts, school-based violence

\footnotetext{
Alexander O. Iyekolo, Ph.D., a Lecturer in the Department of Social Sciences Education, University of Ilorin, Nigeria obtained his Doctor of Philosophy (Ph.D.) (2013) in Sociology of Education from the University of Ilorin, Nigeria. Iyekolo is a registered teacher with the Teachers' Registration Council of Nigeria (TRCN). He is a member of the Association of Sociologists of Education in Nigeria and a Member of the Social Studies Association of Nigeria. Recent Publications include: Akinsemoyin, L. O., Uyanne, E. O., Iyekolo, A. O. \& Yayi, T. O. (2017): Moral education in the Nigerian school setting: An antidote for corruption. Journal of Humanities and Education, 2(2), 50-60; Okafor, I. P., Balogun, A.O., Iyekolo, O. A. \& Abdulaziz, I. (2017). Social deprivations and access to life-saving facilities among tertiary in Ilorin, Kwara State: African Journal of Interdisciplinary Studies, 10, 96-101. Published by Department of Publishing and Web Development, University of Education Winneba Ghana.
} 
Iyekolo

\section{Introduction}

A school environment is a mini society. It is an environment in which people of diverse socio-economic backgrounds and orientations come together for the purpose of acquiring knowledge and social skills. Randle (2000) referred to the school environment as a melting point in which persons of varied social textures come to be molded into a single unified whole which would be appreciable and acceptable by the larger society. One single channel through which this unification is achieved is called social interaction. Social interaction is the conscious and unconscious, through which people within an environment relate and exchange ideas using lettered and unlettered languages - that is using verbal and non-verbal language.

Language is one major instrument of social interaction. Humans, animals, and even plants have manners of communicating their feelings, ideas and intensions through the use of language (Sorioz, 2009). Human beings are known to communicate verbally and non-verbally. Nonverbal communication is the exchange of information and meaning through facial expression, gestures, movement of the body and physical appearance. Non-verbal communication consists of body language, paralanguage, proxemics, touch, artifacts and structures or edifices.

In most cases, many of the non-verbal communications in a school environment are either neglected, mismanaged or under-utilized for school development. Yet, in everyday school activities, teachers, students and school administrative personnel communicate subtle information through what they wear (clothes and school uniform) and through their facial expressions. Also, much is communicated through the way the school environment is arranged and sectionalized.

No doubt, the content, process and pattern of what is communicated in school-based nonverbal messages can go a long way in determining the success of teaching and learning activities. This is because teaching and learning are interactive. Social interaction and academic activities can become fruitless when non-verbal message are not appropriately utilized. In fact, a mismanaged element of communication in the channel of teaching and learning and in school administration can result in school violence (Randle, 2000).

Specifically, interactive conflict and subsequent school violence can result from underutilized non-verbal messages. Interactive conflict in the school environment occurs when schoolstaff and students' academic and social interactions become negative and nonfunctional in committing the school members to achieving the objectives in which they are gathered to interact and achieve. Staffs and students of any given school are gathered to interact and achieve academic and social skill objectives, but their interaction may fail to lead them towards achieving these objectives if they are enmeshed in a communication breakdown and consequently experience interactive conflicts. According to Interactionist Theories, success in human endeavors depends largely on the definitions the parties in those endeavours give to the language, gestures, appearances and manner of others. This paper presents a sociological perspective of what teachers, students, school administrators and the school environment communicates non-verbally in every school day and how conflicts of interaction can result if such communicated messages are uudecoded or under-utilized by significant persons at home, in the school, and in the community. 
Iyekolo

\section{Theoretical Framework}

The three theories applied in this discussion are: Interactionist Theory, Labeling Theory and Self-fulfilling Prophecy Theory. The Interactionist Theorists opine that human interaction is based and/or shaped by meanings people give to other people's statements, behaviour, appearance and emotions. The theories argue that a lot of meanings are embedded in what people do or in the way they appear. Those meanings are crucial in understanding the dynamics of human social interaction and that when not managed adequately, they tend to cause tension among human beings (Giddens, 2001).

Labeling theory opines that people are labeled based on what the do, say, and the way they appear. Thus, an appearance put up by a person can determine whether he/she would be labeled as deviant, delinquent or labeled a conformist or obedient. According to the labeling theorists, when a label is attached to a person by significant persons (e.g. parents, teachers, law enforcement agents etc.), there is tendency for them to see themselves in terms of that label and act accordingly (Giddens, 2001; Horowitz \& Bordens, 1995).

Haralambos and Holborn (2008), in their attempt to explain how labels shape human behaviour mostly in school environment, argue that teachers labeled students and thereafter made the students act out in a particular way. They submit that the teachers' interactions with pupils will be influenced by their label or definition of the behaviour of the students - most of which the students communicate nonverbally. Teachers may, for example, expect higher-quality academic work from their students and give greater encouragement to those with whom they have defined as 'bright' students. Subsequently, the students' self-concept will be shaped by the teacher's expectations. The students will see themselves as ' bright' or 'dull' and act accordingly. Their actions will, in part, be a reflection of what the teacher expects from them. In this way the prophecy is fulfilled.

The following focuses on how elements of non-verbal communication can contribute to the management of school-based violence.

\section{Artifacts and Student's Appearance as Elements of Nonverbal Messages in School Environments}

Artifacts are elements of non-verbal communication that consists of clothing, make-up, hairpieces, eyeglasses, beauty aids, jewelries and shoes/sandals. In the school environment, efforts are made to regularize artifacts at the lower level of schooling by unifying students through school uniform policies. With a school uniform, the school tries to eliminate negative impressions, segregation and inequalities, and instill discipline. But a close look at what staff and students wear can speak volumes regarding their gender, rank, and status. However, when not managed, many school artifacts collectively communicate to the entire society certain things the school may not intend to communicate. 
Iyekolo

\section{What do Artifacts Communicate in a School Setting?}

The school uniform a student wears to school can communicate the care he or she receives at home. It can communicate the level of affluence or poverty at home and it can communicate how tidy his/her immediate home environment is. This non-verbal communication can indicate how the home complements the efforts of the school to achieve a disciplined child. In the same vain, artifacts on teachers can communicate the personality of the teacher and his possible level of commitment to duties (Ayorinde \& Amali, 2010).

A student can communicate his disposition towards youth subculture and subsequently reflects his/her sense of discipline and readiness to engage in an act that can trigger school violence through what he wears and how he/she wears the clothing item. The way students roll up their sleeves, where they place their belt and trousers, and the level to which a shirt is buttoned can speak volumes about a student's sense of discipline. In secondary schools today, students appear in saggy trousers, they roll their sleeves and leave the button undone to communicate their non-compliance with school rules and regulations, to identify themselves with specific school group, and to show their currency in the social milieu of the larger society. When school administrators ignore the meaning or are not knowledgeable about what the clothing items and fads communicate, school conflict and violence may result.

An artifact can also communicate a student's sexual attitude. Students are known to attain and spend their adolescence in secondary schools (Steinberg, 2002). Adolescents are known to be vibrant and highly socially conscious. They express their desire for autonomy and sexual freedom through what they wear in the school environment (Bishop, 1999; Meyer, 1994). As adolescents walk the school compounds, they non-verbally communicate or express their sexuality. An understanding of the subtle messages their appearances communicate non-verbally can help school administrators determine the counseling needs of the adolescents in the school.

The non-verbal communication message sent through what the individual wears in the school compound can also illustrate the pattern of peer interaction. In the school setting, cliques are formed. Cliquing is one way in which students socially map their school environment. Through cliquing, they divide the school compound into the social conscious and less social conscious students, discipline and undisciplined students, and into the deviants and conformant students. Many school cliques are identifiable through their wearing of tattoos. Tattooing is the practice of making permanent designs on the body. It is done by pricking small holes in the skin with a sharpened stick, bone, or needle that has been dipped in pigments with natural colour. Tattoos can communicate negativities. Benjamin (2000) writes that tattoos can symbolize membership with a cult group or dangerous loyalty to some negative behaviour instigators. Thus, a close look at students and even teachers can communicate the orientation they acquire through peer interaction.

\section{Para-languages as an Element of Nonverbal Messages in a School Environment}

Para-languages are another category or element of nonverbal communication. Paralanguages are vocal cues, that surround speech. They include the speaker's voice pitch, volume, pacing of speech, silent pause, and sighs. Para-language has to do with how something is said 
Iyekolo

rather than with what is said. Para-language can provide a rich source of information to the classroom teacher, school counselors, school club handlers, and school administrators who wish to avert school violence within his/her school.

\section{What Para-languages Communicate in the School Setting}

Para-language as a nonverbal element can depict students' and staff temperaments. Through para-languages, teachers can decode how aggressive a student can be and school administrators can, as well, decode how his/her employees handle school discipline. Aggressiveness is anti-education. Ayorinde \& Nndoke, (2009) write that aggression is a major underlining factor in crisis resulting from application of school discipline policies. In a situation of administering corporal punishment, an aggressive teacher can become very dangerous. Paralanguage reveals students' readiness to accommodate other students' opinion as they chat in the classroom.

Para-language also nonverbally informs the listeners about the emotional needs of the speaker. A teacher in a school setting can detect how emotionally stable or wrecked a colleague teacher is by merely listening to the teacher speak. Students can unconsciously reflect on the problems they face at home in their voice pitch, pacing of speech, and silent pauses while speaking. Emotional wreckage obstructs teaching and learning activities (Biehler \& Snowman, 1995). Educational technologists identify emotional instability as 'noise' in the channel of classroom communication (Olumorin, 2009). An emotionally wreaked teacher can not teach adequately just as an emotionally disturbed student may fail to hear, let alone understand, the content of classroom learning.

Through para-languages, a school can also communicate to the outside community within which it is located as to how disciplined the school is. Students' voice volume and pitch can tell the hosting community how academically engaged the students of a school are. A school from which noise is frequently emanating will readily be taken as being a less serious school by the people around the school. Thus, through para-languages, a school can class itself as progressive or unprogressive, and as organized or disorganized.

\section{Body Language and Proxemics as Elements of Nonverbal Messages in the School Environment}

Body languages are physical motions and gestures that communication actors (speaker and listener) display as they communicate. Body languages include the way a communication actor sits, stands, moves his/her hands and/or face while communicating. Kroehler \& Hughes (2002) assert that body language can communicate aggression, receptivity, boredom or hostility. Thus, through body language, students communicate a lot as they listen to lessons, counseling and take instructions. Proxemics, on the other hand, is all about the way communicator actors employ social and personal space while they communicate. For example, where a person sits to listen to a speech can send a message on his/her attitude towards, or interest in, the content of communication. Much can be deduced from sitting arrangements and students' body language in the classroom. 
Iyekolo

\section{What Body Language and Proximics Communicate in the School Setting}

How a student sits, stands, move his/her hands and/or face while listening to a lecture can depict his/her interest in what is being taught and/or his/her likeness for the teacher. Thus, the teacher can assess his students' readiness to learn or the impact of his method of teaching by picking up on the messages being communicated through his students' body language in the classroom. Talking about proximity, Kroehler \& Hugges (2002) opine that students who sit in the front rows of a classroom communicate that they are interested while those in the rear communicate that they are alienated and prone to mischievous activities.

Body language can also be used to assess the impact of counseling exercises on a student being counseled. Counselling exercises in a school setting are initiated to bring about change in behaviour and to guide students on career choices. The body language and proxemics a student being counseled displayed can signal to the counselor whether he/she is achieving his counseling objective. Such a signal can be used in determining whether a new approach should be tried or whether the counseling should be continued or discontinued or whether a referral should be made.

\section{School Name and Facilities as Elements of Nonverbal Messages in the School Environment}

In this age of private ownership of schools, different names are given to schools. Proprietors of schools name their schools after themselves while some religious bodies give religious names to schools (just as in the past when schools owned by the government were called grammar school, comprehensive school, or high school to reflect the educational thinking of the time.) Some school names reflect the focus of the school. For example, a technical college is suggestive of a technological bias. No doubt, deciphering the name of a government school may not be difficult, however, the names of many private schools communicate a lot to customers (i.e. parents wishing to enroll their children in the school) and students. This same idea applies to what the state of available school facilities communicates to the entire community.

\section{What a School Name and Facilities Communicate to the Society}

A name given to a school may communicate the category of students and staff that are expected to be in the school. For example, a school named Al-Hikma may suggest that only Muslim students and staff will be appreciated in the school. Al-Hikma in Arabic means wisdom. The use of Arabic Language rather than English Language in naming the school, particularly in an English-speaking society, may go a long way in determining the influx of students for enrolment into such a school.

Also, the school gate and fence can communicate the school owners' perception of school security. In addition to this, the state of the physical structure, the arrangement of the buildings and even the neatness of the school compound can communicate the seriousness of the school 
business and how organized the school owners are. Schools with a very tall school gate could signify strict policies within the school. In the same vein, planting flowers around the school could mean that the school has a high sense of aesthetics.

The school bus is another element of non-verbal communication that can communicate the financial state of the school and/or how school administrators handle students' safety. Schools that convey students to school in a rickety school bus signals a lack of co-ordination and professional incapability.

\section{School-Based Violence and Interactive Conflicts as Consequences of Negative and Under- utilized Non-verbal Messages}

A failure of schools to decodes a series of nonverbal messages within their learning and administrative environments can spell doom for the progress of the schools and the community within which they are located. One of the immediate consequences of such a failure is interactive conflict. Interactive conflict is a situation of tense interpersonal relationships among school staff and students. It is a situation of breakdown in school decision and communication processes. When interactive conflict become tense and unmanaged, school violence can result. Interactive conflicts can occur when and where the messages through nonverbal communication in school are not deciphered, are left unnoticed and underutilized in ensuring progress in the day-to-day activities of the school.

This segment of discourse illustrates how non-verbal communication initiates interactive conflicts in the secondary school level. An underutilized and negative nonverbal message in a school compound can adulterate the school culture of academics and excellence and install indiscipline in school interaction. Schools are established to instill discipline and academic prowess among students but when negative nonverbal messages in term of artifacts, proxemics and para-languages are injected into the school atmosphere unnoticed by the school authority, disciplinary problems will increase. Students that are not involved in negative nonverbal activities can easily get socialized into the acts, since the acts have pervaded their school compound. Take for example, Rockash, (2009) who writes that students invent examination malpractice strategies in drones and experiment with them in every exam. Such strategies can be nonverbally communicated to school in the way of proxemics (i.e. where and how students sit in exams). A school that fails to read such proxemics in its examinations and nip the act in the bud will have a high incidence of examination malpractices before it knows it.

Unread negative nonverbal messages can segregate the school and cause conflict as they hamper unprejudiced social interaction among staff and students of the school. Many students become isolated and are molested in the school compound because they don't belong to the social milieu of the school. Such students easily get neglected by the teachers in teaching and learning activities. Haralambos and Holborn (2008) writes that teachers' attitudes towards students are often determined by socio-cultural classification within which the teacher places the student. Unfortunately, a student may be very quiet, reserved and passive in the class not because he/she is dull but because he/she finds it difficult to absolve himself/herself into the prevailing negative culture among his/her fellow students (Ayorinde. 2010). A teacher that failed to notice the segregation may erroneously classify the aforesaid student as too passive and thereby neglect the student in his/her teaching. This may eventually derail the students' development of their own 
self-concept. A person's self-concept is the view of himself which develops from interactions with others. Haralambos \& Holborn (2008) assert that interactions in the classroom, with teachers and pupils helps to shape a person's self-concept; and the self-concept can have a significant effect on the person's educational attainment.

Negative labeling is a serious interactive conflict and this may encroach within a school compound when a school's authority fails to real some nonverbal messages among staff and students. Labeling theory argues that once a label is attached to a person, there is tendency for them to see themselves in terms of the label and act accordingly. There is also a tendency for others to see them in terms of the label and act towards them on that basis. Students in our schools are labeled as deviant or conformist on the basis of what they communicate through their artifacts, body language, paralanguages and proxemics (Krochler \& Hughes, 2002). Thus, a student that is labeled deviant or delinquent by his teacher because of what he nonverbally communicates may become more delinquent and unable to be rescued behaviorally because there is the tendency that he would be alienated by teachers and other behaved students and may have no choice than to interact with others that are also labeled as delinquent.

\section{Conclusion}

Elements of non-verbal communication can not be ignored by school administration. This is because such communication can go a long way in presenting the school as academically conscious or unconscious. Mismanaged non-verbal communication cues can render the school ungovernable for school administrators. 
Iyekolo

\section{References}

Ayorinde, S. A. (2010). Criminal intent and educational aspiration of disadvantaged school-age hawkers in two selected north central cities of Nigeria. Journal of Historical Sciences in Education, 6(1), 116-126.

Ayorinde, S. A. \& Amali, I. O. O (2010). Influence of personality traits and gender on commitment to duties among urban public secondary school teachers in Kogi State. Lapai Sociological Review, 2(1), 95-107.

Ayorinde, S. A. \& Ndoke, H. I. (2009). Advantages of using alternatives to corporal punishment in teaching Nigerian primary and secondary school students. Nigerian Journal of Sociology of Education, 3(3), 181-189.

Bishop, A. T. (1999). Social psychology. New York: plenty-well.

Benjamin, R. Y. (2000). Language art in modern society. Boston: Rod Millers Inc.

Brehler, R. F. \& Snowman, J. (1982). Psychology applied to teaching. Boston: Houghton Mifflin company.

Giddens, A. (2001). Sociology. New York: Policy press.

Horowitz, L. A. \& Bordens, K. S. (1995). Social psychology. London: Mayfield publishing company.

Haralambos, M. \& Heald, R. M. (2008). Sociology: Themes and perspectives. New York: Oxford University press.

Kroehler, J. C. \& Huges, K. G. (2002). Behavioural development in group situations. Boston: MaGraw.

Meyer, D. I. (1994). School administration: A sociological approach. Boston: Yaros-Hollinger company.

Olumorin, O. O. (2009). Educational technology. Ilorin: Trinity printing press.

Randle, S. I. (2000). The art of language and communication. Mexico: Frenter-Albenter.

Rockash, T. K. (2009). Learning to be rude. New York: Daily digest

Soriez, S. S. (2009). The beauty of communication: A socio-linguistic perspective. Journal of Social Psychology, 3(2), 26-31.

Steinberg, M. D. (2002). Adolescence. New York: McGregor Hills. 